\title{
PENGEMBANGAN MEDIA PEMBELAJARAN BAHASA BERBASIS LINGKUNGAN DAN TEKNOLOGI
}

\author{
Haryadi, Tadkiroatun Musfiroh, dan Suwardi Endaswara \\ Fakultas Bahasa dan Seni, Universitas Negeri Yogyakarta \\ email: itadzung@yahoo.co.id
}

\begin{abstract}
ABSTRAK
Media pembelajaran berbasis lingkungan dan teknologi diperlukan untuk meningkatkan efektivitas pembelajaran. Permasalahannya adalah bagaimana mengembangkan media berbasis lingkungan dan teknologi yang tepat untuk pembelajaran bahasa Indonesia dan Jawa. Penelitian ini menggunakan jenis penelitian pengembangan (R\&D) multy years yang dilakukan tiga tahun berturut-turut. Tahun pertama telah dihasilkan 2 storyboard media pembelajaran bahasa berbasis lingkungan dan 2 storyboard media pembelajaran bahasa berbasis teknologi. Penelitian tahun ke-2 telah menghasilkan 4 media, yakni media kartu kata, media menyimak dengan adobe media-flash, solikata, dan media menulis. Hasil uji-coba media yang dihasilkan menunjukkan hitungan: rerata 3,67 untuk media kartu kata (kategori baik), rerata 4,00 media diskusi adobe media-flash (kategori baik), rerata 3,7 untuk media solikata (kategori baik), dan rerata 3,65 untuk media berbahasa Jawa (kategori baik). Kelebihan media ini terletak pada inovasi dan fleksibiltas sasaran (SMP dan SMA), kemudahan evaluasi. Kekurangan media terdapat pada durasi. Seiring dengan selesainya produk dan uji coba, beberapa media disosialisasikan dalam bentuk artikel melalui majalah/jurnal penelitian. Tahap ketiga akan dilakukan desiminasi produk. Selanjutnya, media yang telah dihasilkan akan diajukan untuk mendapatkan HaKi.
\end{abstract}

Kata kunci : media, bahasa, lingkungan

\section{THE DEVELOPMENT OF THE MEDIA FOR ENVIRONMENT AND TECHNOLOGY BASED-LANGUAGE LEARNING}

\begin{abstract}
The media for environment and technology based-learning are needed to improve the effectiveness of learning. The problem is how to develop the environment and technology based-media which are appropriate for Indonesian and Javanese language learning. This research is a three-year research and development (R\&D). The results of the first year of this three-year research are two storyboards for the environment based-language learning media and two storyboards for the technology based-language learning media. The products of the second year of this three-year research are four language learning media, namely word card media, adobe media-flash, solikata, and writing media. The tryout result shows that the average of each media usage is 3.67 (good) for word card media, 4.00 (good) for adobe media-flash, 3.7 (good)for solikata, and 3.65 (good) for media in Javanese language. The advantages of the media lie in the innovation and flexibility, the flexibility of the targets (either junior high school or senior high school), and the simplicity of the evaluation. The disadvantage of the media is its duration. As the products and the try-outs were finished, some articles and journals are made to inform people about these media. In the third year of this research, product dissemination will be conducted, and the media produced will be registered as intellectual property.
\end{abstract}

Keywords: media, language, environment

\section{PENDAHULUAN}

Penggunaan media dalam pembelajaran memiliki arti dan pengaruh yang besar, terutama terkait dengan indera siswa. Penggunaan media dalam proses kegiatan belajar-mengajar lebih menjamin terjadinya pemahaman yang lebih 
baik pada siswa. Siswa yang belajar melalui indera pendengar (mendengar ataupun mendengarkan) saja akan memiliki tingkat pemahaman dan kekuatan memori yang berbeda dengan peserta didik yang belajar melalui dua indera sekaligus, yakni indera mata dan telinga.

Media bukan sekedar penghantar materi, tetapi juga sarana membangkitkan imajinasi, minat, dan membawa siswa agar mampu tercipta suasana yang menyenangkan dan menggembirakan. Media mampu memantik keterlibatan emosi dan mental. Media mampu memberikan semangat belajar dan menghidupan suasana pembelajaran sehingga pemahaman siswa terhadap materi ajar meningkat. Kehadiran media, dengan demikian, memperjelas informasi pada waktu tatap muka sekaligus memperkaya materi, meningkatkan efektivitas dan efisiensi, menambah variasi, dan memberikan cakrawala yang lebih luas dari apa yang diberikan guru tanpa media. Media juga dapat mengkonkretkan materi yang relatif abstrak, serta menambah perhatian siswa. Pendek kata, media memiliki peran yang besar dalam pembelajaran.

Meskipun media memiliki banyak kelebihan, fakta di lapangan menunjukkan hal sebaliknya. Media belum dimanfaatkan secara optimal oleh guru. Guru masih menggunakan media yang ada dan belum menciptakan mediamedia alternatif yang sesuai dengan kebutuhan. Lingkungan sebagai sumber pembelajaran belum banyak diolah sebagai media yang "appropriate", demikian halnya dengan komputer dan internet. Padahal, pesatnya teknologi informasi mengharuskan guru memberikan sajian materi yang selalu baru dan berdaya guna. Dengan kata lain, perputaran informasi yang demikian pesat menuntut guru memanfaatkan teknologi. Apabila tidak dilakukan, dipastikan pembelajaran akan membosankan karena terjadi gap antara materi dengan interes peserta didik.

Pembelajaran bahasa, baik bahasa Indonesia, bahasa Inggris, maupun bahasa daerah, merupakan mata pelajaran yang bertumpu pada abilitas kognisi dalam dua ranah utama, yakni aktif reseptif dan aktif produktif. Abilitas ini menuntut kemampuan subkognitif, kognitif, dan komunikatif. Membaca, misalnya, sebagai bagian dari kegiatan aktif reseptif, menuntut kemampuan yang kompleks, dari mengetahui bentuk satuan lingual, memahami maknanya, mengambil makna dalam konteks, mengkomunikasikan, memberikan sanggahan, sampai pada memberikan argumentasi. Paradigma expert ke novice dari behaviouristik tidak mungkin mampu melayani kebutuhan dengan baik dalam hal ini. Bagaimana pun, paradigma baru, bahwa pengetahuan dan abilitas adalah sebuah konstruksi individu yang lebih berterima. Hal ini berarti peran media tidak dapat diabaikan. Apabila tidak terpenuhi, pembelajaran akan menjadi ajang doktrinasi, penjinakan kognitif; suatu kondisi yang menghalangi perkembangan kreativitas siswa dan menghambat pencapaian higher order thinking.

Proses konstruksi ilmu melalui asimilasi dan akomodasi. Berdasarkan paradigma ini, maka prinsip media mediated instruction menjadi penting dan cukup strategis. Dalam konteks ini, dibutuhkan guru yang mampu dan siap berperan secara profesional (Heinich et.al., 2002). Dalam era perkembangan Iptek yang begitu pesat dewasa ini, guru diharapkan mampu mengelola informasi dan lingkungan untuk memfasilitasi kegiatan belajar siswa (Ibrahim, $d k k$., 2001). Guru diharapkan mampu mengolah tempat belajar, metode, media, sistem penilaian, serta sarana dan prasarana yang diperlukan untuk mengemas pembelajaran dan mengatur bimbingan belajar sehingga memudahkan peserta didik belajar.

Perkembangan Iptek, sebenarnya, membawa dampak positif terhadap proses pembelajaran yakni diperkaya sumber dan media pembelajaran, seperti buku teks, modul, film, video, overhead transparansi, televisi, slide, hypertext, webblog dan website. Guru profesional diharapkan mampu memilih, menggunakan, bahkan menciptakan berbagai jenis media pembelajaran yang ada di sekitarnya. Dengan demikian, media membawa dampak positif, bukan hanya ekstensi materi tetapi juga kedalamannya, serta membantu proses konstruksi karena keterlibatan berbagai indera siswa selama proses belajarmengajar terjadi.

Selain media artifisial, guru pun dituntut mampu memanfaatkan media natural (seperti peristiwa, lingkungan, proses alam) dalam proses pembelajaran. Apa pun yang ada di sekitar lingkungan sekolah, sepanjang terjangkau dan 
relevan dengan tujuan pendidikan dapat dimanfaatkan. Dengan kata lain, guru dituntut mampu memanfaatkan media, baik media berbasis lingkungan maupun media berbasis teknologi. Keberadaan keduanya menjadi penting mengingat media merupakan salah satu komponen komunikasi, yaitu sebagai pembawa pesan dari komunikator menuju komunikan (Criticos, 1996).Pengembangan media yang berorientasi pada peningkatan abilitas berbahasa (menyimak, membaca, menulis, berbicara) mendesak dilakukan mengingat kemampuan menulis pelajar Indonesia sangat rendah, pun kemampuan membaca.

Perlu ditegaskan bahwa fokus penelitian ini adalah mengembangkan media pembelajaran bahasa berbasis lingkungan, mengembangkan media pembelajaran bahasa berbasis teknologi, dan outline panduan pemanfaatan media. Dengan demikian, masalah utama dalam penelitian ini adalah bagaimana media pembelajaran yang tepat digunakan untuk pembelajaran bahasa berbasis lingkungan, berbasis teknologi, dan bagaimana pula panduan penggunaannya.

\section{Pengembangan Media}

Media menurut Soeparno (1988: 1) adalah suatu alat yang dipakai sebagai saluran (channel) untuk menyampaikan suatu pesan (message) atau informasi dari suatu sumber (resource) kepada penerima (receiver). Dalam bidang pendidikan pesan atau informasi berasal dari guru, sedangkan penerima informasi adalah siswa. Pesan yang disampaikan berupa sejumlah kemampuan yang perlu dikuasai oleh siswa. Kemampuan yang harus dikuasai pesertya didik mencakup tiga ranah, yaitu (1) ranah kognitif, (2) ranah afektif, dan (3) ranah psikomotor. Kemampuan yang harus dikuasai peserta didik dikomunikasikan melalui berbagai saluran, yaitu penglihatan (visual), pendengaran (audio), penglihatan dan pendengaran (audio-visual), perasaan (sense), dan penanpilan (performance).

Berkembangnya komunikasi elektronik, membawa perubahan-perubahan besar dalam dunia pendidikan. Satu hal yang harus dihindari yaitu anggapan bahwa kedudukan guru akan digantikan oleh alat elektronik. Dengan demikian, keberadaan komunikasi elektronik, seharusnya tidak menafikan kehadiran guru, justru harus menambah pentingnya kehadiran guru.

Pengembangan media pembelajaran didasarkan pada tiga model pengembangan yaitu model prosedural, model konseptual, dan model teoretik. Model prosedural merupakan model yang bersifat deskriptif, yaitu menggariskan langkah-langkah yang harus diikuti untuk menghasilkan produk. Model konseptual yaitu model yang bersifat analitis yang memerikan komponen-komponen produk yang akan dikembangkan serta keterkaitan antarkomponen. Sementara itu, model teoretik adalah model yang menunjukkan hubungan perubahan antarperistiwa.

Kehadiran media pembelajaran sebagai media antara guru sebagai pengirim informasi dan penerima informasi harus komunikatif, khususnya untuk objek secara visualisasi. Dalam pembelajaran ilmu pengetahuan alam, khususnya konsep yang berkaitan dengan alam semesta lebih banyak menonjol visualnya, sehingga apabila seseorang hanya mengetahui kata yang mewakili suatu objek, tetapi tidak mengetahui objeknya disebut verbalisme. Tiap-tiap media mempunyai keistimewaan menurut karakteristik siswa. Pemilihan media yang sesuai dengan karakteristik siswa akan lebih membantu keberhasilan pengajar dalam pembelajaran. Secara rinci fungsi media memungkinkan siswa menyaksikan objek yang ada tetapi sulit untuk dilihat dengan kasat mata melalui perantaraan gambar, potret, slide, dan sejenisnya mengakibatkan siswa memperoleh gambaran yang nyata (Degeng,2001:19).

Menurut Gerlach dan Ely (dalam Arsyad, 2002:11) ciri media pendidikan yang layak digunakan dalam pembelajaran adalah (1) Fiksatif (fixative property): Media pembelajaran mempunyai kemampuan untuk merekam, menyimpan, melestarikan, dan merekonstruksi suatu peristiwa/objek; (2) Manipulatif (manipulatif property): Kejadian yang memakan waktu berhari-hari dapat disajikan kepada siswa dalam waktu dua atau tiga menit dengan teknik pengambilan gambar time-lapse recording; (3) Distributif (distributive property): Memungkinkan berbagai objek ditransportasikan melalui suatu tampilan yang terintegrasi dan secara bersamaan objek dapat menggambarkan kondisi 
yang sama pada siswa dengan stimulus pengalaman yang relatif sama tentang hal itu.

Dari penjelasan tersebut dapat disimpulkan bahwa media pembelajaran berfungsi menampilkan serangkaian peristiwa nyata yang terjadi dalam waktu lama dapat disajikan dalam waktu singkat. Suatu peristiwa yang digambarkan mampu mentransfer keadaan sebenarnya, sehingga tidak menimbulkan adanya verbalisme.

Proses belajar mengajar dapat berhasil dengan baik jika siswa berinteraksi dengan semua alat inderanya. Guru berupaya menampilkan rangsangan (stimulus) yang dapat diproses dengan berbagai indera. Semakin banyak alat indera yang digunakan untuk menerima dan mengolah informasi, semakin besar pula kemungkinan informasi tersebut dimengerti dan dapat dipertahankan dalam ingatan siswa. Siswa diharapkan akan dapat menerima dan menyerap dengan mudah dan baik pesan-pesan dalam materi yang disajikan.

Keterlibatan siswa dalam kegiatan belajar mengajar sangat penting. Edgar Dale (Soeparno, 1988:5) mengemukakan kerucut pengalaman yang terdiri dari sepuluh tingkat, yairu (1) verbal, (2) lambang visual, (3) lambang visual dan verbal, (4) lambang verbal, visual, dan gerak, (5) pameran, (6) studi wisata, (7) demonstrasi, (8) dramatisasi, (9) pengalaman tiruan, dan (10) pengalaman langsung. Dalam hal ini partisipasi, observasi, dan pengalaman langsung memberikan pengaruh yang sangat besar terhadap pengalaman belajar yang diterima siswa. Penyampaian suatu konsep pada siswa akan tersampaikan dengan baik jika konsep tersebut mengharuskan siswa terlibat langsung dibandingkan dengan konsep yang hanya melibatkan siswa untuk mengamati saja.

Media pembelajaran berbeda dengan alat pelajaran maupun alat peraga. Alat pelajaran adalah alat yang dipakai untuk menunjang berlangsungnya proses belajar-mengajar. Jadi alat pelajaran semata-mata dipandang dari segi hardware-nya saja. Dengan kata lain alat pelajaran adalah hardware yang belum diisi atau tidak diisi dengan program. Media menurut Soeparno (1988:3), merupakan paduan antara hardware dan software. Software (perangkat lunak) adalah suatu program yang disisikan pada hardware.
Sementara itu, alat peraga pada hakikatnya hanya merupakan alat yang berfungsi menvisualisasikan suatu konsep tertentu saja.

Perangkat media mencakup: material, equipment, hardware, dan software. Istilah material berkaitan erat dengan istilah equipment dan istilah hardware berhubungan dengan istilah software. Material (bahan media) adalah sesuatu yang dapat dipakai untuk menyimpan pesan yang akan disampaikan kepada audien dengan menggunakan peralatan tertentu atau wujud bendanya sendiri, seperti transparansi untuk perangkat overhead, film, filmstrip, dan film slide, gambar, grafik, dan bahan cetak. Equipment (peralatan) ialah sesuatu yang dipakai untuk memindahkan atau menyampaikan sesuatu yang disimpan oleh material kepada audien, misalnya proyektor film slide, video tape recorder, papan tempel, papan flanel, dan sebagainya.

Istilah hardware dan software tidak hanya dipakai dalam dunia komputer, tetapi juga untuk semua jenis media pembelajaran. Contoh, isi pesan yang disimpan dalam transparansi OHP, kaset audio, kaset video, film slide. Software adalah isi pesan yang disimpan dalam material, sedangkan hardware adalah peralatan yang digunakan untuk menyampaikan pesan yang telah dituangkan ke dalam material untuk dikirim kepada audien. Contoh, proyektor overhead, proyektor film, video tape recorder, proyektor slide, proyektor filmstrip.

Menurut J. Kemp (Soeparno, 1988;13) media dapat diklasifikasi ke dalam lima kelompok, yaitu (1) permainan dan simulasi, (2) media pandang, (3) media dengar, (4) media pandang dengar, dan (5) media rasa. Menurut Gagne (1985), media dapat diklasifikasi menjadi tujuh kelompok, yaitu (1) benda untuk didemonstrasikan, (2) komunikasi lisan, (3) media cetak, (4) gambar diam, (5) gambar bergerak, (6) film bersuara, dan (7) mesin belajar. Ketujuh kelompok media pembelajaran tersebut dikaitkan dengan kemampuannya memenuhi fungsi menurut hierarki belajar yang dikembangkan, yaitu pelontar stimulus belajar, penarik minat belajar, contoh prilaku belajar, memberi kondisi eksternal, menuntun cara berpikir, memasukkan alih ilmu, menilai prestasi, dan pemberi umpan bal 
Pemahaman atas klasifikasi media pembelajaran tersebut akan mempermudah para guru atau praktisi lainnya dalam melakukan pemilihan media yang tepat pada waktu merencanakan pembelajaran untuk mencapai tujuan tertentu. Pemilihan media yang disesuaikan dengan tujuan, materi, serta kemampuan dan karakteristik siswa akan sangat menunjang efisiensi dan efektivitas proses dan hasil pembelajaran.

Media berbasis lingkungan terdiri dari peristiwa, gejala alam, dan lingkungan tiga dimensi lain, termasuk lingkungan sosial. Media berbasis lingkungan yang digunakan dalam pembelajaran bahasa dapat disebut sebagai sebuah eco-linguistic. Media ini merupakan pemberdayaan lingkungan di sekitar peserta didik, yang dipandang lebih kontekstual dalam pembelajaran bahasa. Asumsi dasar pemakaian media berbasis lingkungan adalah belajar bahasa atas dasar akar lingkungan, agar siswa tidak tercerabut dari lingkungannya. Mengenal lingkungan sekitar menandai bahwa peserta didik semakin mudah, akrab, dan senang belajar bahasa secara total. Benda-benda atau barang di sekitar siswa merupakan "guru utama" dalam belajar bahasa. Dengan benda-benda tiga dimensi yang diamati langsung oleh siswa, jelas akan memudahkan seorang yang belajar bahasa.

Lingkungan banyak menyediakan media tiga dimensi yang lebih menarik untuk medium belajar bahasa. Siswa dapat mengenal bahasa dengan cara mengingat, menyimpan sebagai pengetahuan (knowledge), dan akhirnya mereka memiliki ability to articulate. Artinya, dengan menggunakan media tiga dimensi siswa akan mudah untuk mengartikulasikan bahasa.

\section{Media Berbasis Teknologi}

Media berbasis teknologi dapat diklasifikasikan ke dalam dua kategori dasar, yakni berbasis komputer dan berbasis web (internet). Salah satu media berbasis teknologi adalah $b l o g$ dan website.Blog pada mulanya bernama "weblog" namun kata "weblog" tersebut disingkat menjadi blog. BLog pada dasarnya merupakan website dengan ciri khusus, yakni tulisan terbaru berada paling atas. Blog mengikuti format diari (catatan harian) online atau jurnal yang isinya dibuat berdasarkan tanggal.
Berdasarkan hal tersebut, sangat jelas blog memiliki karakteristik dan kelebihan yang dapat dijadikan media alternatif dalam pembelajaran menyimak dan menulis berita. Belajar bahasa melalui blog peserta didik akan semakin tertata dalam menerima dan mengekspresikan ide. Blog dapat memudahkan peserta didik belajar bahasa secara informatif.

\section{METODE PENELITIAN \\ Jenis Penelitian}

Penelitian ini termasuk penelitian riset dan pengembangan (R\&D) yang dilakukan selama tiga (3) tahun. Riset awal dilakukan pada tahun 2012 dilanjutkan dengan penelitian hibah pada tahun ke-2 (tahun 2013), ditindaklanjuti dengan penelitian multy years selama tiga tahun.

Tahun pertama mengkaji penggunaan media pembelajaran bahasa di SMP dan SMA dan kendala operasionalnya, merancang draf media berbasis lingkungan untuk pembelajaran bahasa integratif pertama, merancang draf media berbasis teknologi untuk melakukan pembelajaran bahasa integratif, menyelenggarakan FGD dengan responden ahli dan guru untuk membahas draf media dan melakukan revisi.

Tahun kedua memvalidasi mediamedia yang telah dikembangkan pada tahun pertama, mengembangkan panduan penggunaan media dan menyelenggarakan FGD untuk membahas draf panduan, melakukan uji-coba media di sekolah dan merevisi produk media dan panduan, dan tahun ketiga diseminasi media dan panduan yang dihasilkan ke guru-guru serta pihak terkait, merevisi jika masih diperlukan, produksi massal, dan pengusulan HAKI HC.

\section{Subjek Penelitian}

Pada tahun pertama, responden yang dilibatkan pada FGD adalah 15 guru bahasa Indonesia dan bahasa Jawa dari Kabupaten Sleman. Tahun kedua, dilibatkan 3 ahli untuk validasi media, 12 guru untuk validasi media dan panduan, serta 6 guru dan 180 siswa untuk uji coba. Pada tahun ketiga, model diseminasikan ke 5 dinas pendidikan kabupaten kota di DIY, wakil perguruan tinggi, dan LPMP, dan MGMP. Dalam diseminasi itu, diharapkan dihadiri oleh 5 orang utusan dinas pendidikan, 3 wakil PT, 2 
wakil LPMP, dan 20 orang guru utusan MGMP, 2 orang dari perguruan tinggi.

\section{Metode Pengumpulan Data}

Metode pengumpulan data tahun pertama penelitian ini adalah diskusi wawancara, observasi, dan angket. Observasi dilakukan di sekolah yang masuk dalam kategori bagus, sedang, dan kurang untuk melihat proses pembelajaran dan penggunaan media. Dalam hal ini dilakukan juga wawancara dan pengisian angket guna menemukan kebutuhan riil media pembelajaran bahasa lengkap dengan kendala yang ada, termasuk kekuatan dan kelemahatan materi yang ada. Focus Group Discussion (FGD), digunakan untuk menjaring pendapat tentang draf media yang diinginkan, FGD berfungsi dua, yakni sebagai trianggulasi need asessment sekaligus sebagai validasi awal draf media. FGD dengan para pakar dilakukan dengan memberikan draf media dan ringkasan panduan. FGD dilakukan bersama 15 guru bahasa Indonesia dan bahasa Jawa utusan dari MGMP.

Pada tahun kedua, digunakan metode wawancara, FGD, angket, tes, dan observasi. wawancara, FGD, angket digunakan untuk desk evaluation dan validasi pengguna. Observasi, tes, dan wawancara digunakan untuk uji-coba. Pada tahun ketiga, digunakan metode angket dan observasi produk oleh ahli.

\section{Teknik Analisis Data}

Data yang terkumpul akan dianalisis menggunakan teknik deskriptif kualitatif dan kuantitatif. Teknik deskriptif kuantitatif digunakan untuk mendeskripsikan berapa responden yang hadir dan memberi masukan, berapa responden yang hadir tetapi tidak memberi masukan, serta berapa responden yang tidak hadir. Sementara itu, teknik statistik deskriptif kualitatif digunakan untuk mendeskripsikan perilaku guru dan siswa dalam proses pembelajaran bahasa, mendeskripsikan kriteria media yang dibutuhkan, dan mendeskripsikan keterbatasan pihak sekolah terkait dengan media.

\section{HASIL DAN PEMBAHASAN Hasil Penelitian}

Dalam penelitian ini dihasilkan empat media pembelajaran bahasa, yaitu(1) kartu kata untuk pembelkajaraan hasa Indonesia; (2) Solikata untuk pembe;lajaran bahasa Indonesia; (3) media pembelajaran diskusi; (4) media pembelajaran bahasa Jawa berbasis geguritan. Salah satu contoh media yang dihasilkan adalah kartu kata, yang bentuk dan cara permainannya sebagai berikut.

\section{Bentuk Media Kartu Kata}

Kartu kata disusun dengan memanfaatkan kartu dalam permainan remi. Permainan remi mudah dilakukan dan banyak dilakukan oleh masyarakat, dan dapat temukan di berbagai tempat. Cara memodifikasi kartu remi menjadi kartu kata mengikuti langkah berikut ini. Pertama, kartu remi yang terdiri dari empat kelompok (sekop, waru, kriting, dan wajik, dan setiap kelompoknya terdiri dari 13 lembar, yaitu angka 2-10 ditambah J, K, Q dan A) dimodifikasi sehingga dihasilkan media pembelajaran bahasa Indonesia berbasis permainan remi.

Kedua, kartu yang telah dimodifikasi bermuka dua dengan motif yang berbeda dengan remi. Muka pertama bermotif batik dengan tulisan KAMI BANGGA, CINTA, SADAR, SETIA TERHADAP BAHASA INDONESIA. Muka kedua di tengahnya kosong, sedangkan di tepinya terdapat motif ukiran dan lambang bilangan sesuai dengan jumlah motif ukiran yaitu 2 sampai 10, sedangkan sebagian lagi bermotif ukiran dengan huruf B,C,S, dan BI.

Ketiga, kartu permainan terdiri dari 52 kartu dengan rincian: 36 kartu bermotif ukiran dengan lambang bilangan 2 sampai 10 sebanyak 4 set; 16 kartu kartu dengan motif ukiran berkode huruf B (bangga), C (cinta), S (sadar/ setia) BI (Bahasa Indonesia) masing-masing 4 set.

Keempat, kartu permainan dapat ditulisi huruf, suku kata, kata, dan kalimat sesuai dengan materi pembelajaran yang akan disampaikan. Tulisan dapat dihapus atau diganti.

Kelima, kartu kata dengan tulisan berupa huruf untuk pembelajaran merangkai huruf menjadi kata; suku kata untuk pembelajaran kata, kata untuk pembelajaran kalimat, dan kalimat untuk pembelajaran paragraf. 
Cara Bermain dengan Kartu Kata

1) Pemain terdiri dari 4 orang, yang selanjutnya dapat dimodifikasi antara 2-5 orang sesuai kebutuhan.

2) Kartu yang sudah dimodifikasi dan diberi tulisan sesuai keperluan diacak dengan cara dikasut oleh salah seorang pemain.

3) Pengasut membagikan kartu satu per satu kepada setiap pemain dengan urutan seperti perputaran jarum jam atau sebaliknya, dimulai dari pemain di sebelah kanan/kiri pengasut sehingga setiap pemain mendapatkan tujuh kartu.

4) Sisa kartu diletakkan di tengah meja permainan dengan posisi tertutup, artinya bagian bawah bermotif ukiran dengan tulisan suku kata, kata atau kalimat, dan bagian atas bermotif batik.

5) Permainan selanjutnya adalah pengambilan kartu perdana oleh pengasut dari tumpukan kartu, yang kemudian dibanting atau diletakkan dalam posisi terbuka (dibeber).

6) Permainan dilanjutkan dengan pengambilan satu kartu dari tumpukan atau dari beberapa kartu bantingan (beberan kartu terbuka).

7) Setiap pemain berusaha menyusun kartukartu yang diambil atau dimiliki menjadi kata, kalimat atau paragraf.

8) Kartu-kartu yang sudah dapat dirangkai menjadi kata, kalimat atau paragraf dianggap sudah jadi (satu set) dan kemudian diletakkan di atas meja dalam posisi terbuka.

9) Kartu yang terletak di tangan tidak boleh lebih dari tujuh kartu, sehingga pemain yang kartu di tangannya lebih dari tujuh kartu terkena sanksi tidak boleh melanjutkan permainan dan atau permainan dianggap selesai dan pemain tersebut dianggap kalah dengan terkena sanksi pengurangan nilai 50 butir.

10) Permainan berlanjut sampai dengan tumpukan kartu itu habis terambil oleh para pemain.

11) Pemenang dalam permainan ditentukan berdasarkan jumlah kartu yang mampu disusun oleh para pemain menjadi kata, kalimat atau paragraf.

\section{Modifikasi Permainan}

1) Jumlah pemain dapat ditambah atau dikurangi yaitu dari empat orang menjadi dua atau lima orang.

2) Bentuk bahasa yang dituliskan dapat dimodifikasi sesuai dengan tujuan pembelajaran. Kartu suku kata untuk pembelajaran kosakata, katu kata untuk pembelajaran kalimat, dan kartu kalimat untuk pembelajaran paragraf.

3) Jumlah bentuk susunan bahasa yang disiapkan oleh guru dapat bervariasi misalnya satu set, dua set,atau empat set. Bahkan, apabila diperlukan dapat dimodifikasi menjadi beberapa set.

4) Kartu pemain yang sudah jadi dan diletakkan dalam posisi terbuka di atas meja boleh diambil oleh pemain lain bila diperlukan atas dasar persetujuan sebelum permainan dimulai.

5) Kartu bantingan (beberan) yang diambil hanya dapat digunakan untuk melengkapi posisi awal atau akhir susunan bahasa yang akan dibentuk atau disepakati untuk sembarang posisi.

6) Apabila diperlukan untuk pengintegrasian dengan berhitung/matematika (CALISTUNG) penentuan pemenang berdasarkan jumlah kartu yang tersusun atau berdasarkan penjumlahan angka yang kartu yang tersusun.

7) Permainan dapat dimulai dengan membaca Sumpah Pemuda butir 3 "Kami putra dan putri Indonesia menjunjung bahasa persatuan, bahasa Indonesia" dan diakhiri dengan menyanyikan lagu "Padamu Negeri."

\section{Hasil Uji-Coba Media}

Hasil uji-coba media dilakukan untuk mengukur kualitas media dari berbagai aspek. Media "kartu kata" diuji-coba dengan 18 butir kriteria penilaian, media "solikata" diuji-coba dengan 20 butir kriteria, media "menyimak diskusi" diuji-coba dengan 5 komponen, yakni format, tampilan, isi, bahasa, dan pembelajaran. Tiap-tiap komponen terdiri atas beberapa butir kriteria. Demikian pula dengan media "menulis bahasa Jawa", penilaian uji-coba didasarkan pada 5 komponen dengan beberapa butir kriteria. 
Berdasarkan hasil uji coba kemudian didapatkan rekomendasi guna perbaikan media pembelajaran. Setelah media direvisi untuk mendapatkan kualitas media yang lebih baik. Untuk mengetahui kualitas media yang sudah direvisi maka dilakukan lagi pengukurannya. Apabila hasil uji-coba pertama sudah memenuhi persyaratan, yakni baik), maka media tidak diperbaiki.

Selanjutnya, untuk dapat diinterpretasikan, skor hasil pengukuran dikonversikan ke dalam tabel konversi berikut ini.

Tabel 1. Konversi Skor

\begin{tabular}{cc}
\hline Skor & Predikat \\
\hline 4,1 ke atas & Sangat baik \\
$3,4-4,0$ & Baik \\
$2,7-3,3$ & Cukup \\
$1,9-2,6$ & Buruk \\
Kurang dari 1,8 & Sangat buruk \\
\hline
\end{tabular}

Konversi tersebut diterapkan pada rerata, yakni hasil penjumlahan dibagi jumlah butir kriteria. Hal ini berbeda dengan interpretasi terhadap skor mentah. Skor mentah terendah adalah 1 dan skor tertinggi adalah 5. Butir kriteria yang dinilai 1 berarti sangat rendah, 2 rendah, 3 sedang, 4 tinggi, dan 5 sangat tinggi.

\section{Media Kartu Kata}

Hasil uji coba media kartu kata menunjukkan rerata keseluruhan 3.67 (baik). Komponen yang mendapatkan predikat sangat baik (skor 4,1-5,0) ialah (1) penggunaan bahasa, (2) kemudahan dalam evaluasi. Komponen yang mendapat predikat baik (skor 3,4-4,0) ialah (1) kemudahan memilih menu, (2) kemenarikan untuk pembelajaran, (3) kejelasan petunjuk penggunaan, (4) tampilan teks, (5) tata letak, (6) komposisi dan kombinasi warna, (7) alur kegiatan, (8) relevansi dan sistematika materi, (9) kegiatan memotivasi siswa, (10) kesesuaian dengan perkembangan kejiwaan, (11) fleksibilitas penggunaan, (12 kemudahan penggunaan, (13) kebermaknaan dalam pemahaman materi, (14) kemanfaatan dalam pencapaian kompetensi. Komponen yang berpredikat cukup (skor 2,73,3 ) ialah (2) relevansi gambar. Komponen yang berpredikat buruk (skor 1,9-2,6) ialah (1) ke- sesuaian waktu dalam proses pembelajaran. Setelah direrata, media kartu kata termasuk dalam kategori baik sehingga tidak perlu direvisi.

Kesesuaian waktu yang proses pembelajaran mendapatkan skor rendah sehingga berpredikat buruk. Hal ini dapaat dimaklumni sebab pembelajaran di kelas dibatasi waktu sementara dalam permainan kartu kata sangat bergantung pada kemampuan setiap pemain atau kelompok bermain. Untuk mengatasi hal ini, kartu kata dapat digunakan dengan ketentuan waktu seperti berlaku di kelas yaitu 40 menit. Konsekuansinya, ada kemungkinan permainaan belum selesai. Meskipun demikian, permainan bisa diakhiri. Penentuan pemenang dihitung berdasarkan ketentuan yang ada, yaitu pemain yang paling banyak berhasil merangkai kartu akan jadi pemenangnya. Selanjutnya, secara berurutan pemenang ditentukan berdaparkan perolehan kartu yang sudah jadi.

\section{Media Solikata}

Uji coba penggunaan media permainan solikata mendapat rerata 3.70 (baik). Komponen yang berpredikat sangat baik (skor $>4,1$ )ialah (1) relevansi gambar penggunaan bahasa, (2) kemenarikan media. Komponen yang berpredikat baik (skor 3,3-4,0) ialah (1) kemudahan memilih menu, (2) alur kegiatan, (3) kegiatan memotivasi siswa, (4) kemudahan penggunaan media, (5) kebermaknaan dalam pemahaman materi, (6) kemanfaatan dalam pencapaian kompetensi, (7) fleksibilitas media, (8) kejelasan petunjuk , (9) tampilan teks, (10) tampilan video, (11) tampilan suara, (12) tata letak, (13) komposisi dan kombinasi warna. Komponen yang berpredikat cukup (skor 2,7-3,3) ialah (1) relevansi dan sistematika materi, (2) kemudahan dalam evaluasi, Sementara itu, komponen yang berpredikat buruk (skor $<2,6$ ) ialah (1) kesesuaian waktu dalam proses belajar. Secara keseluruhan rerata yang dihasilkan berkategori baik, yakni 3,70.

Kesesuaian waktu dalam proses pembelajaran mendapatkan skor rendah sehingga berpredikat buruk. Hal ini dapat dimaklumi sebab waktu pembelajaran di kelas belum tentu cukup untuk menyelesaikan keseluruhan permainan. Hal ini sangat bergantung pada kemampuan para pemaian. Mereka yang sudah 
mahir dapar menyelesaikan permainan lebih cepat daripada mereka yang kurang mahir. Bahkan, untuk mereka yang belum mahir kadang berkali-kali harus mengulang permainan sejak awal (resert) berkali-kali. Kalu hal ini terjadi pasti akan memakan waktu cukup lama.

Untuk mengatasi hal ini, permainan solikata dapat dimodifikasi. Waktu untuk bermain solikata ditentukan lebih dahulu sesuai dengan jam yang berlaku di kelas, misalnya 40 menit. Setelah waktu yang disediakan habis, permainan solikata harus segera diakhiri. Konsekuensinya adalah ada kemungkinan permainaan belum selesai. Meskipun demikian, keberhasilan setiap pemain dalam permainan ini tetap dapat diketahui. Untuk menghitung perolehannya, setiap pemain dapat menjumlahkan kartu yang sudah dapat tersusun menjadi kalimat dengan baik.

\section{Media Pembelajaran Diskusi}

Uji coba media pembelajaran "Menyimak Diskusi" dilakukan untuk mengukur kualitas dari aspek tampilan, format, isi, bahasa, serta penerapannya dalam pembelajaran. Uji-coba ini dilakukan di hadapan 10 orang guru SMP pada tahap sebelum revisi dan 10 orang guru SMP lain setelah melalui revisi.

Dari hasil uji coba pada Tabel 2 terlihat peningkatan kualitas media cukup signifikan dari aspek tampilan dan format dari 'cukup' menjadi 'baik'. Aspek isi dan bahasa meningkat pula dari 'baik' menjadi 'sangat baik'. Adapun aspek pembelajaran meningkat tajam dari 'cukup' menjadi sangat baik.

\section{Media Pembelajaran Menulis Bahasa Jawa}

Media "Menulis Bahasa Jawa" juga diuji-coba, dua kali yakni sebelum revisi dan setelah revisi. Uji coba media ini dilakukan untuk mengukur kualitas dari aspek tampilan, format, isi, bahasa, serta penerapannya dalam pembelajaran. Uji-coba ini dilakukan di hadapan 5 orang guru SMP pada tahap sebelum revisi dan 5 orang guru SMP lain setelah melalui revisi. Hasil uji-coba selengkapnya dapat dilihat pada halaman lampiran.

Dari hasil uji coba Tabel 3 terlihat peningkatan kualitas media cukup signifikan dari aspek tampilan, format, Bahasa, dan Pembelajaran dari 'cukup' menjadi 'baik'. Aspek isi meningkat pula dari 'baik' menjadi 'sangat baik'.

\section{PENUTUP}

Keberadaan media, di SMP dan SMA, sangat dibutuhkan karena berbagai alasan. Media bukan saja berfungsi membantu siswa memahami materi tetapi juga membuat suasana belajar yang menyenangkan dan multiindrawi.

Tabel 2. Interpretasi Hasil Uji-Coba Media Menyimak Diskusi.

\begin{tabular}{lcccc}
\hline \multirow{2}{*}{ Aspek Penilaian } & \multicolumn{3}{c}{ Hasil } \\
\cline { 2 - 5 } & \multicolumn{2}{c}{ Sebelum Revisi } & \multicolumn{2}{c}{ Sesudah Revisi } \\
\cline { 2 - 5 } & skor & predikat & skor & predikat \\
\hline Tampilan & 2,94 & Cukup & 3,7 & Baik \\
Format & 3,04 & Cukup & 3,74 & Baik \\
Isi & 3,53 & Baik & 4,1 & Sangat Baik \\
Bahasa & 3,7 & Baik & 4,28 & Sangat Baik \\
Pembelajaran & 3,07 & Cukup & 4,4 & Sangat Baik \\
\hline
\end{tabular}

Tabel 3. Interpretasi Hasil Uji-Coba Media Menulis Bahasa Jawa.

\begin{tabular}{lcccc}
\hline \multirow{2}{*}{ Aspek Penilaian } & \multicolumn{3}{c}{ Hasil } \\
\cline { 2 - 5 } & \multicolumn{2}{c}{ Sebelum Revisi } & \multicolumn{2}{c}{ Sesudah Revisi } \\
\cline { 2 - 5 } & Skor & Predikat & Skor & Predikat \\
\hline Tampilan & 2,94 & Cukup & 3,4 & Baik \\
Format & 2,97 & Cukup & 3,5 & Baik \\
Isi & 3,53 & Baik & 4,1 & Sangat Baik \\
Bahasa & 2,86 & Cukup & 3,5 & Baik \\
Pembelajaran & 3,00 & Cukup & 3,8 & Baik \\
\hline
\end{tabular}


Penelitian ini berusaha menggali berbagai media berbasis lingkungan dan teknologi yang bertebaran tetapi luput dari perhatian para guru.

Penelitian riset dan pengembangan ( $R$ \& D) yang bersifat multy years ini dilakukan selama tiga (3) tahun. Pada Tahun kedua, yakni tahun 2014 ini telah dihasilkan empat media yang telah divalidasi dan diuji-coba, yakni media kartu kata, media diskusi dengan adobe media flash, media solikata berbasis komputer, dan media pembelajaran menulis untuk bahasa Jawa. Berdasarkan hasil uji-coba itulah, empat media yang dihasilkan telah diperbaiki, yaitu kartu kata, media menyimak dengan adobe media-flash, solikata, dan media menulis. Hasil uji-coba media tersebut menghasilkan (1) rerata 3,67 untuk media kartu kata (kategori baik), (2) rerata 4,00 media diskusi adobe media-flash (kategori baik), (3) rerata 3,7 untuk media solikata (kategori baik), dan (4) rerata 3,65 untuk media berbahasa Jawa (kategori baik). Kelebihan media ini terletak pada inovasi dan fleksibilitas sasaran (SMP dan SMA), kemudahan evaluasi. Adapun kekurangan media terdapat pada durasi. Selanjutnya, media telah diperbaiki berdasarkan masukan melalui FGD dan hasil observasi dalam proses uji-coba media di lapangan. Pada tahun ketiga ini akan dilakukan uji efektivitas, dilakukan sosialisasi media kepada pengguna. Selain itu, akan dilakukan pendaftaran HaKiatau HC, segera setelah uji efektivitas dilakukan. Tahun ketiga juga akan menghasilkan artikel jurnal.

\section{DAFTAR PUSTAKA}

Arsyad, A. 2002. Media Pembelajaran, edisi 1. Jakarta: PT. Raja Grafindo Persada.

Criticos, C. 1996. Media selection. Plomp, T \& Ely, D.P (Eds): International Encyclopedia of Educational Technology, $2^{\text {nd }}$ ed. UK: Cambridge University. Press. pp. $182-185$.

Degeng, N. S. 2001. Media Pembelajaran. Dalam kumpulan makalah PEKERTI (Pengembangan Keterampilan Instruntur) untuk Quatum Teaching. Karya tidak diterbitkan.

Gagne, R. M. 1985. The Condition of Learning and Theory of Instruction, $4^{\text {thed. New }}$ York: CBS College Publishing.

Gagne, R.M., Briggs, L.J \& Wager, W.W. 1988. Principles of Instruction Design, $3^{\text {rd }} \mathrm{ed}$. New York: Saunders College Publishing.

Heinich, R., Molenda, M., Russell, J. D., \& Smaldino, S.E. 2002. Instructional Media and Technology for Learning, 7th edition. New Jersey: Prentice Hall, Inc.

Heinich, R., Molenda, M., \& Russel, J.D. 1993. Instructional Media and the New Technologies of Instruction, $4^{\text {th }}$ ed. New York: Macmillan Publishing Company.

Ibrahim, H., Sihkabuden, Suprijanta, \& Kustiawan, U. 2001. Media Pembelajaran: Bahan Sajian Program Pendidikan Akta Mengajar. FIP. UM.

Soeparno. 1988. Media Pengajaran Bahasa. Klaten: Intan Pariwara. 